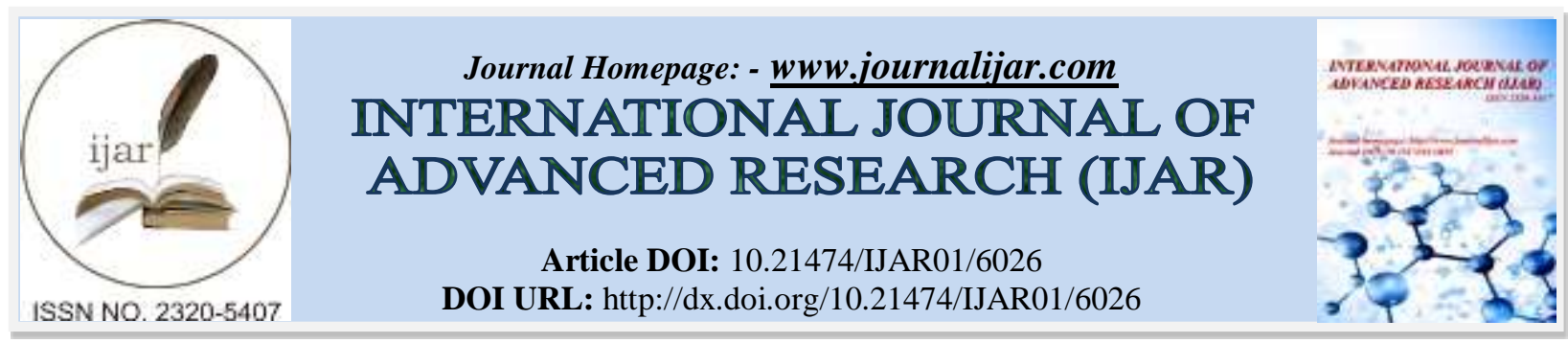

RESEARCH ARTICLE

\title{
TEACHERS' QUALIFICATION: STATUS, EXPERIENCES AND CONCERNS IN A FOURTH CLASS MUNICIPALITY IN EASTERN RIZAL, PHILIPPINES.
}

\author{
Dr. Julieta ST. Fulgado (Principal Author).
} Prof. Glenn M. Ison (Co-author).

\section{Manuscript Info}

Manuscript History

Received: 10 October 2017

Final Accepted: 12 November 2017

Published: December 2017

Key words:-

Teacher Qualifications, Subject Specialists, Out-Of-The Field Teaching, Mismatched Teaching.

\begin{abstract}
This research aimed to analyze the status, experiences and concerns of the teachers who teach subjects which mismatch their major subjects. This utilized the Quantitative-Qualitative method involving documentary analysis, survey and interview type. This involved the teacher-respondents considering sex, major and teaching loads. Significant facts were noted on the status, experiences and concerns of teachers teaching subjects that are not their major in consideration of the many aspects of instructional delivery. This strongly established that teachers who specialized in major subjects experienced their difficulties in handling subjects that mismatched subject they specialized. Among the findings in the concerns are focused on the availability of modules, availability of e-materials prescribed in the module, upgrading of teachers in the content aspects of the subjects they are teaching, evaluation and feedback of students' performance, enhancement on questioning skills as well as trainings in instructional delivery strategies and instructional material preparations.
\end{abstract}

Copy Right, IJAR, 2017, All rights reserved.

\section{Introduction:-}

Teachers are the primary foundation of an educational system. Ngada in Fajonyomi (2007) intensified that the accomplishment or failure of any educational program depends mainly on the ample supply of professionally qualified, competent and committed teachers. In any educational system, teachers are the best important factor where the quality of education is concerned, as teachers are being appraised, student learning and attainment are considered (Ohio TES, 2015).

Rice (2003) mentioned that teacher quality matters. Teachers, from all education levels perform huge tasks of generating conditions and emerging processes for building human skills and capabilities that are considered to be essential for economic growth, prosperity, social well-being, and individual development. Valisno (2012) reiterated that a great teacher in every academic room is a long time concern in the Philippine education system and around the world. It has continued to be an issue in vying for reforms, for nothing has a bigger impact than a teacher on the quality of a young citizen's education.

Semillano (2015) emphasized that teachers are expected to have solid background to analyze and to evaluate learning tasks and instructional materials. They are also expected to have a clear understanding of their field to relate in all areas in the curriculum. Effective teachers of other subjects tend to acquire an updated knowledge based 
in those subjects. It consists of knowledge about content, background about children and their learning and how to teach the effectively (Medwell, 1998).

However, in situations that there are insufficient number of teachers; teachers are also tasked to handle other subjects. In the case of the schools within the fourth class municipality in Rizal Province and considered as the farthest part of the province, it was noted that there were inadequate number of teachers to handle some subjects. This led to assign teachers with no choice but to teach subjects that are not their major, thus mismatch of teaching load and subject specialization occurs.

School heads take the task to come to a decision who teaches, which courses and programs; they also have a remarkable degree of judgment in these decisions. While teachers are required to comply to state certification requirements that assure their preparation foundation and competence, few policies cover of how teachers are employed and utilized once on the job. Policies on teacher employment are not totally enforced and most states usually allow school administrators not to apply even the limited requirements are needed (Education Week 2000, 2003; Robinson 1985). In this situation, assigning teachers to take care of subjects that mismatched their field as useful and acceptable become a routine. Instead of hiring a new science teacher to teach science curriculum, a school head tends to hire couple of English and social studies teachers to each "cover" a section or two in science for convenience. And if a teacher leaves in the middle of a semester, the head may choose to let a readily available, but less qualified substitute teacher than initiate a formal search for a new one.

To address this, harmonizing specialization in teaching background with teaching load for public school teachers has been a prime concern of the Department of Education; guides to lessen pointless academic variance between too much specialization in teaching preparation and teaching loads of public elementary and high school teachers, and the inappropriateness between teacher qualifications and subject assignments were disseminated. (DO 13, s. 1994). However, in the fourth class municipality, there are justifiable factors in which handling subjects that mismatch the major subjects is the only option such as the proximity of the schools, number of student population and number of teacher applicants.

In this paper the researchers analyzed some common thoughts about the teachers' academic background which represents one of the components of the expected teacher qualities and the status, experiences and concerns in handling the subjects. As believed, the teachers' background and preparation has something to do with the students' successes. The students' achievement is the exact measure of usefulness and has become basis for added feature of teacher assessment systems (Braun, 2005; McCaffrey, Lockwood, Koretz, Louis, \& Hamilton, 2004; Sanders, 2000; Sanders \& Rivers, 1996); thus, concerns of the teachers assigned to teach other subjects should be addressed to also address their needs and thereby positively affect the students' achievement and their teaching performance.

\section{Methodology:-}

Generally, the purpose of the study was to establish the status, identify the experiences and the concerns of teachers handling other subjects that are not their major in the fourth class municipality in Eastern Rizal, Philippines teacherparticipants in terms of sex, major, teaching load (specialization) and teaching load (non-specialization). The study utilized twenty-four (24) teachers from the three (3) selected national high schools in the fourth class municipality in Eastern Rizal, Philippines. The researchers utilized quantitative-qualitative method which describes trends including a systematic, actual, accurate and objective situation, problem, or phenomenon as the same time explore and understand a central occurrence (Garcia, 2003; Creswell, 2002). This involved survey and interview on the experiences and concerns of the teachers.

\section{Results:-}

Table 1:- Profile of the two-groups of participants

\begin{tabular}{|c|c|c|}
\hline Sex & f & \% \\
\hline Male & 10 & 41.67 \\
\hline Female & 14 & 58.33 \\
\hline Total & $\mathbf{2 4}$ & $\mathbf{1 0 0}$ \\
\hline
\end{tabular}

Table 1 above shows that in terms of sex, out of twenty four (24) teacher participants there are ten (10) or $41.67 \%$ male teachers and fourteen (14) or 58.33 female teachers. 
Table 2:- Profile of the teacher-participants in terms of major or specialization.

\begin{tabular}{|c|c|c|}
\hline Major & F & \% \\
\hline Math & 6 & 25 \\
\hline Drafting & 1 & 2.17 \\
\hline Science & 6 & 4.17 \\
\hline Agro & 1 & 25 \\
\hline English & 6 & 4.17 \\
\hline GC & 1 & 4.17 \\
\hline Filipino & 1 & 4.17 \\
\hline Accounting & 1 & 4.17 \\
\hline TLE & 1 & $\mathbf{4 . 1 7}$ \\
\hline Total & $\mathbf{2 4}$ & \\
\hline
\end{tabular}

In terms of major, $75 \%$ of the total number of respondents are teachers of the core courses which are English, Science and Mathematics. It can also be perceived that the department still prioritizes these subjects to be taught by the specialized teachers. This may from the confirmation that there is a result in education and educational assignments on a teacher's efficiency (Ashton \& Crocker, 1987; Everston, Hawley, \& Zlotnik, 1985; Ferguson \& Womack, 1993, Guyton \& Farokhi, 1987).

Table 3:- Profile of the teacher-participants in terms of teaching loads.

\begin{tabular}{|c|c|c|c|c|c|}
\hline Teacher & Frequency & $\begin{array}{c}\text { Specialization } \\
\text { Load }\end{array}$ & Frequency & $\begin{array}{c}\text { Non-Specialization } \\
\text { Load }\end{array}$ & Frequency \\
\hline Math & 6 & Math & 4 & $\begin{array}{c}\text { Science } \\
\text { MAPEH } \\
\text { AP }\end{array}$ & 1 \\
\hline Drafting & 1 & & 0 & MAPEH & TLE \\
\hline Science & 6 & Science & 3 & English & 1 \\
& & & & TLE & 1 \\
\hline Agro & 1 & & & ICT & 1 \\
\hline English & 6 & & & MAPEH & 2 \\
\hline GC & 1 & English & & MAPEH & 3 \\
\hline Filipino & 1 & & & Filipino & 1 \\
\hline Accounting & 1 & & & MAPEH & 1 \\
\hline TLE & 1 & & & MAPEH & 1 \\
\hline
\end{tabular}

It can be gleaned that although teachers are handling subjects that they are specialized, along with the rest, there are teachers who are teaching subjects that are not their specialization. Based on the interview, they consider that other subjects are easier to teach and that they expect teachers to be flexible. This was an evidence that in the department, teachers are given other subjects to teach even though it is not their specialization specifically those who have just taken supplemental units in professional education.

\section{Result of Interview:-}

1. What are the problems met in teaching subjects that are not your major?

2. What activity/ program do you think will address the difficulties you encountered in teaching subjects that are not your major?

\section{Summary of Needs based on the questions:-}

1. Modules are available, but, with the limitations of the background, there is a need to upgrade the teachers in content aspects specifically those who are teaching TLE subjects; 
2. Some module contents are with videos that are supposed to be downloaded yet not available anymore; teachers are encouraged to explore more on available videos, and/or video clips should be made available to all through CD's.

3. Questioning skills should be improved since most teachers were limited to dimensional questions;

4. More trainings in instructional delivery strategies and instructional material preparations which will compensate the shortness of the allotted period per subject.

\section{Discussion:-}

Professional Background, Preparation, Specialization and Students Achievement:-

Harmonizing specialization in teaching background with teaching load for public school teachers has been a prime concerns of the Department of Education; guides to lessen pointless academic variance between too much specialization in teaching preparation and teaching loads of public elementary and high school teachers, and the inappropriateness between teacher qualifications and subject assignments were disseminated. (DO 13, s. 1994).

This feature is related to the subject-matter background teachers got during their schooling and pre-service training. The proof from varied studies is contradictory. There are studies which revealed a relationship between teachers' preparation in the subject matter they later teach and student achievement (Darling-Hammond, 1999, 2000; Goldhaber \& Brewer, 2000; Guyton \& Farokhi, 1987), while others have less clear results. Monk and King (1994) found both positive and negative effects of teachers' actual field preparation on student achievement. Goldhaber and Brewer (2000) found a positive relationship in Mathematics, but none in Science. Also, Rowan, Chiang, and Miller (1997) reported a positive relationship between student achievement and teachers' majoring in mathematics. Monk (1994), however, found that having a major in Mathematics has no effect, and a significant negative effect of teachers with more teaching load in Physical science. As mentioned by Syed ( 2009), measurement of teachers competence related to the performance by the students is quite difficult though the evaluation procedures largely depend on the output of their students.

School heads take the task to come to a decision who teaches, which courses and programs; they also have a remarkable degree of judgment in these decisions. While teachers are required to comply to state certification requirements that assure their preparation foundation and competence, few policies cover of how teachers are employed and utilized once on the job. Policies on teacher employment are not totally enforced and most states usually allow school administrators not to apply even the limited requirements are needed (Education Week 2000, 2003; Robinson 1985). In this situation, assigning teachers to take care of subjects that mismatched their field is a useful and acceptable become a routine. Instead of hiring a new science teacher to teach science curriculum, a school head tends to hire couple of English and social studies teachers to each "cover" a section or two in science for convenience. And if a teacher leaves in the middle of a semester, the head may choose to let a readily available, but less qualified substitute teacher than initiate a formal search for a new one.

Semillano (2015) reiterated that teachers are expected to have solid background to analyze and to evaluate learning tasks and instructional materials. They are also expected to have a clear understanding of their field to relate in all areas in the curriculum.

Effective teachers of other subjects tend to acquire an updated knowledge based in those subjects. It consists of knowledge about content, background about children and their learning and how to teach the effectively (Medwell, 1998).

This is proven by several studies such as on the impact of a high calibre, performing teacher inside the classroom. In a study by Barber and Mourshed (2009), over the years, learning with an effective teacher instead with a teacher with low performance result can attain only 53-percentile variation for two students who began at the equal accomplishment level. From this, the researchers thought about the teachers' specialization background and the subjects being taught could have an effect on the performance of the students since in the Philippine scenario, it was observed that as professionally qualified teachers enter the field meaning those who have reached or exceeded the entry standard set by the department, they are given loads that are not their specialization for many reasons.

Recent researches in the USA on the issue of mismatched teaching, Ingersoll (2003) shows a stern condition where almost $42 \%$ - 49\% of public Grade 7-12 teachers handle science and mathematics in fact do not have a full 
qualification in the field (1999-2000 data). In Israel, based on current survey (Maagan, 2007), these percentages are even higher for elementary teachers $-42 \%$ in mathematics and 63\% in science (2005-2006data).

This is supported by an investigation that revealed a stronger impact of education and academic assignments on teacher effectiveness (Ashton \& Crocker, 1987; Everston, Hawley, \& Zlotnik, 1985; Ferguson \& Womack, 1993, Guyton \& Farokhi, 1987). Some researches relate the consequence of courses in educational subject matter to that of courses in the subject matter itself and present proof for the pedagogical subject matter courses (Monk, 1994) in mathematics although other studies that education courses show no effect on students' science achievement (Goldhaber \& Brewer, 2000).

In other countries, Student achievement is one of the strongest bases of future income (Hanushek 2011; Hanushek and Woessman 2009; Hanushek and Zhang 2009; Lazear 2003; Mulligan 1999), but there is a prime achievement gap among racial and socioeconomic lines in the U.S., with minority and poor students not performing as well as their white or well-off peers (Barton and Coley 2009). Several factors contribute to these achievement gaps, however, with the largest impact — and also those most easily remedied by policy changes are school factors such as adjustments to curriculum, class size, availability of technology, teacher training and know-how (Barton and Coley 2009). Teacher's worth, specifically, is considered as the most significant variable in the students' achievement, more than demographic factors (Darling-Hammond 2000).

Aaronson, Barrow and Sander (2007) mentioned in their study that students do not only learn from an ineffective teacher, but their academic performance actually tends to go down. In addition, Sanders and Rivers' study showed that students assigned to a highly effective teacher after being with ineffective teachers were able to attain high results, but were not able to cope the missed learning. These studies bring the idea that each teacher has an direct and lifelong effect on student achievement.

In order to elevate student achievement, effort on educational research has focused on the advancement of highly qualified teachers (Greenwald, Hedges, \& Lain, 1996; Hedge, Lain, \& Greenwald, 1994). Researchers and policymakers have taken into consideration the upgrading for teacher quality as the best means to make progress on student achievement (DarlingHammond, 2002; Greenberg, Rhodes, Ye, \& Stancavage, 2004). For instance, the "No Child Left Behind Act" need all teachers handling the academic subjects should be highly competent until 20052006 school year" (Greenberg et al., p. 1). Specifically, most eligible teachers are mandatory to (a) get full state certification, (b) have adequate topic background and teaching skills, and (c) hold at least a bachelor's degree (Greenberg et al.).

\section{Mismatched Specialization and the Need for Upgrade on Contents for Subject load:-}

Other than teaching competencies, based on interview, subject content background of the teacher poses a problem, accordingly, with the change of curriculum, Modules are available, but, with the limitations of the background, there is a need to upgrade the teachers in content aspects specifically those who are teaching TLE subjects; Even though a teacher passed the licensure examination even if his background is on business, and he is given a TLE subject, still he faces a dilemma to deliver the lessons since this subject has a wide scope ranging from electricity, agriculture and plumbing.

It may seem that an official recognition for subject specialization could possibly equip the teachers; this shall provide them solid background on the topics they should teach. This possible suggestion is sustained by the practice in other countries that for a teacher to qualify to teach another subject, they should undergo training and certification (Ingersoll, 2003).

Some results related to teachers' academic degrees (e.g., bachelors or masters, etc.) are uncertain. Some studies showed affirmative effects of advanced degrees (Betts, Zau, \& Rice, 2003; Ferguson \& Ladd, 1996; Wayne \& Youngs, 2003), while others showed opposite effects (Ehrenberg \& Brewer, 1994; Kiesling, 1984). Some disagree that the requisite of a second degree raises the rate in terms of teacher background and the time it involves and may deter quality candidates from choosing this vocation (Murnane, 1996).

Typically, policymakers, critics, and researchers have believed two connected reasons for the progressing problem of mismatched teaching. One engages the sufficiency of credentials and training of teachers; the other involves the sufficiency of the number of teachers produced. The first holds that mismatched teaching is a problem of poorly 
prepared teachers. With regard to this, teacher pre-service background or university training programs, and that mandated by state certification standards, require ample rigor, breadth and depth, especially in academic and substantive coursework, resulting in high levels of mismatched teaching. (e.g. Darling-Hammond 1999; American Council on Education 1999; Soler 1999; Toch 1996; Committee for Economic Development, 1996).

As a number of teacher quality measures are considered to give the feature between a high and low quality teacher, certification rank is often considered the most reliable and strong basis. To be an expert teacher, it basically needs formal schooling in a state-recognized education program, the achievement of either a major or minor in the subject field, and a minimum accomplishment of education credits and internship credits (DarlingHammond 2000).

Professional growth tasks can be carried out by varied groups, in schools and out of school, on the job or on time off leave. On these events, active teachers on practice upgrade their content background and teaching competence to fit in the new curricula. Assessment has been leveled on the intermittent nature of these activities and the point that very little is recognized about what they really consist of. There is varied validation on the effect of teachers' contribution in professional development tasks on student outcomes. However, there are some inquiry results on inservice professional development, which are established no effect (Angrist \& Lavy, 2001, Jacob \& Lefgren, 2004), while other revealed that higher levels of student attainment were linked to mathematics teacher participation in content-specific pedagogy tasks correlated to the curriculum (Brown et al.,1995; Cohen \& Hill, 1977; Wiley \& Yoon, 1995). Wenglinsky (2000) reveled an affirmative effect of expert development tasks that focus on the requirements of special education students, on higher-order skills, and on laboratory skills in science. Harris and Sass (2007) recognized the "lagged effect of professional development", i.e., the superior effect of professional development three years after the implementation. The correlation between students' success and teacher professional development activities does not encourage to make conclusions about a underlying relation, as this variable is related with other attributes of teachers, i.e., participating teachers are likely to also be more motivated and, usually, more expert in the subjects they handle.

Professional development is activities that develop an individual skill, knowledge, expertise and other characteristics as a teacher (Ogundele, 2014). It is a cognizant and orderly procedure to make certain that teachers are advancing for continuous self-improvement (Oluremi, 2013). Professional development is vital to the retention and enhancement of teachers (The American Association of Physics Teachers, 2009).

Professional development is an aspect of teachers' qualifications that is dominant for a successful classroom teacher. Oluremi (2013) said professional development improves teachers' teaching skills. This author pointed out that there was the call to promote teacher's continuous professional advancement to manage successfully to raise the quality of education. Teachers' continuous professional development is highly significant both to improving educational performance and effectiveness, and for enhancing teachers' commitment, identity and job contentment (European Commission, 2013) .

Agharuwhe (2013) cited Wenglinsky that professional development is related positively to students' achievement. Professional development helps active teachers to improve their content knowledge and teaching skills to fine-tune to new curricula

\section{The Need to Supplement Instructional materials:-}

Based on interview with the respondents, another concern was, some module contents are with videos that are supposed to be downloaded yet not available anymore.

Rolluqui (n.d.) mentioned that in the Philippines, teachers utilize an educational learning that is practical which is done by providing multi-media aided education and resources suited to the diverse types of learners. With Multimedia instruction, teachers and students attain logical and innovative skills that enable them to think independently and to become updated and dynamic members of the society (Dela Pena, 2012).

Specifically, the K to 12 Araling Panlipunan Curriculum was printed and made available by January 31, 2012. As of the middle of the school year, some of the learning resources for teachers and students for Grade 1 and 7 were already used but some were still underway. The learning resources for this include teaching guides, curriculum guides, learning guide/modules and activity sheets. There are certain characteristics of modules, namely: it should 
encourage independence, self-sufficient; self-instructional; distinct; has clear, definite objectives; observes provision for individual difference, has structured order of knowledge; there is provision for learning opportunities; uses a diverse media; encourages active sharing; gives immediate reinforcement of responses; promotes mastery of evaluation strategy; and performs assessment of the work (Macarandan, 2014).

However, some prescribed multimedia materials are not available, so teachers are encouraged to explore more on available videos, and/or video clips should be made available to all through CD's for distribution, reproduction and utilization.

This is supported by the result and recommendation in the study of Rolluqui (n.d.), the stated useful instructional media in different levels, despite of the subjects assigned to them, is multi-media. The teachers can better apply different types of instructional media with the use of computer technology. It is most relevant that the teachers have access to up to date hi-tech equipment, software and practical training to create and employ successful, modernized instructional resources and teachers be encouraged through training in the utilization of instructional media especially in the basic education.

\section{Questioning Skills for the K-12 Learners:-}

Another concern was on teachers' clamor for questioning skills that should be improved since most teachers were limited to dimensional questions. One of the targets of teaching is not only to appraise learning results but also to direct students on their learning course. A teacher may differ his or her purpose in asking during the discussion or a single question may have more than one purpose (Fries-Gaither, 2013). Hence it is imperative that, as teachers; they inquire about the students' thinking and learning process. Teachers could ask students to give details how they arrived at their conclusion and in doing so, what sort of material they had used and if the resources had provided adequate facts (Sockalingam, 2011), For example, to examination if a student can assess what has been learned, the teacher could ask the student to analyze a theoretical difficult circumstance (Ohio Department of Education, Instructional Management System, 2011).

In general, research says that questioning is more helpful than merely giving instruction without questioning. Inquiring is a research-based strategy which was included in Classroom Instruction That Works (Marzano, Pickering, and Pollock 2001). One significant finding is that, it focuses student attention on main fundamentals of a lesson that end in better comprehension than those that focus on odd or unappealing elements. Questions should also be prepared so that most draw out accurate replies.

It is necessary for teachers to note the dynamics of classroom communication sways students' perceptions and sharing in classroom activities, and then it may make them to monitor and regulate the patterns of classroom communication to arrive at an environment that is favourable to learning and acquisition of a second language. Classroom is considered as a distinctive communication context. The patterns of classroom communication eventually settle the students' participation in classroom tasks by using the language, and the opportunities and efficiency of the acquisition of the target language. Questioning clearly supports classroom communication. Questions are elicit thinking, start inquiry (International Education Studies November, 2008) and create relationships. Yet, it is relevant to recognize that not all questions attain these (Xiaoyan Ma (2008).

Teachers may recompense their lack of questioning skills such as preparing and the questions in a lesson. Identify the number of lower cognitive questions? Higher cognitive questions? If the set of questions fit the age and capacity level of learners? predict probable answers, especially partly right or inaccurate responses. How will teachers address redirect questions to probe? A colleague may be asked to monitor a lesson, looking at the types of questions and answers. Convene to talk about the comments and prepare for enhancement. Taking video of one's self while delivering a lesson, document the wait-time for both the teacher and students. Detailed feedback can be examined, resources and other means of professional growth that can help them improve their questioning techniques (Sockalingam 2011).

\section{Professional Advancement on Instructional Delivery Strategies and Preparation of Supplementary Materials:-}

The teacher respondents are also concerned about trainings in instructional delivery strategies and instructional material preparations which will compensate the shortness of the allotted period per subject. 
During the early implementation of the new curriculum, there had been trainings for teachers but Roger Bartholomew (2013) from the International Education Specialists said it worries him that the schools are, at that point, still developing teacher training that hasn't been tried and tested. His suggestion was to look at trainings that has already been proven effective in other countries and universities. He said that the desire to raise the bar, schools have to go to places with a high bar, grab some of their best ideas, and be aggressive to borrow them.

Teachers feel despite of mass trainings for teachers of different grade levels every summer. They feel that these trainings are not sufficient enough specifically if the subjects loads are not what they attended to; the learners' modules and teachers' guides which were introduced and disseminated are not enough since these seem not tried out and tested yet. (FGD session, 2015).

It is significant to study the reliability of the conclusion on well-equipped teachers and high-quality teaching issue. It is also to understand what exact qualities of teachers, and the academic settings have a say to successful student outcomes. This can aid in identifying how to support successful teachers. If high-quality teaching is vital to the accomplishment in students' education and if the academic achievement of students can be related to exact features of teaching - such information may be utilized to argue on recent trend in a lot of districts toward dilution of requirements for teacher education and certification as an answer to lack of teacher, reduction of class-size, and growing K-12 learner's populations ( National Academy of Science, 2016).

Other than teaching strategies for effective instructional delivery, teachers may prepare supplementary materials to cope with the subjects they are teaching, they should learn to prepare engaging materials. Research has recognized that students in the learning course increases their consideration and focus, motivates them to rehearse higher-level critical thinking skills and endorse significant learning experiences. Instructors who take on a student-centered move towards teaching boost the prospect for student engagement which then assists each person successfully attain the course's learning objectives (Marzano, 2008). No resource can totally convene the needs of individual teachers and their learners: everyone will necessitate adjustment with particular groups of students. While textbooks may be fixed and unchangeable - a resource can truly be systematic - they are, like other resources, initial points for teaching and learning and can be supplemented, modified or changed to fit teaching goals and students' interests (Littlejohn, 1998).

These Instructional resources may vary from guided learning coursework, particularly printed materials, pictures, directed reading, using the libraries materials, assignment of work for lecture comments or for computer appraisal, self appraisal problems, exercises and questions, material connected to other form of teaching e.g. notes on broadcast programmes; instructions for the use of scientific kits. Aijaz Ahmed Gujjar and Muhammad Ashraf Malik (2007).

Printed materials are considered vital and noteworthy. The motivation to learning which it provides depends mainly on the coaching skills which it integrates, and on the progressive mastery of the topic which the student gets from it. Printed material can offer the core round which an integrated chain of broadcast programmes, of directed activities, of discussion groups and vis a vis teaching can, as resources allow, be built up for all these reasons, the package of printed material dispatched to the students at standard intervals is an essential part of distance learning systems.

Somehow, they will be able to compensate materials that are lacking, if the time is not enough to attain mastery, they could also provide instructional materials for extended learning fitted to the students' interest and leading to the attainment of expected competencies.

\section{Conclusions:-}

It can be concluded that the students under the instruction of specialist teachers performed better than the students under the instruction of non-specialist teachers. The presence of a highly-qualified and trained teacher in a classroom resulted in better and higher level of academic performance. There are aspects that should be considered to assist the non-specialist in teaching subjects such as upgrading in content aspects specifically the Technical and Livelihood Education subjects, training in questioning skills, instructional delivery strategies and instructional material preparations and creating a set of available copies of audio-visual materials. 


\section{References:-}

1. Aijaz Ahmed Gujjar and Muhammad Ashraf Malik ( 2007). Preparation Of instructional material for distance teacher education. Turkish Online Journal of Distance Education-TOJDE January 2007 ISSN 1302-6488, Volume: 8 Number: 1 Article: 4. Retrieved August 30, 2016 from http://files.eric.ed.gov/fulltext/ED494809.pdf

2. Anandarun P.(2011). Modular Method of Teaching. Retrieved on February 5, 2015 fromhttp://anandkab.blogspot.com/2011/04/modular-method-ofteaching.html

3. Boiser, D.C. (2004). Teaching made easy: Strategies and style. Phoenix Publishing House, Inc. Quezon Ave. Quezon City.

4. California Teaching Performance Assessment ( CALTPA). ( 2008). Retrieved August 29, 2016 from http://www.ctc.ca.gov/educator-prep/TPA-files/CandidateHandbook-AppendixA-TPEs.pdf

5. DO 13, s. 1994. Guidelines for Matching Specialization in Teaching Preparation with Teaching Assignments for Public School Teachers. Retrieved August 29, 2016 from http://www.deped.gov.ph/orders/do-13-s-1994

6. Fries-Gaither, J.(2008). Questioning Techniques: Research-Based Strategies for Teachers. Ohio State University. Retrieved August 30, 2016 from http://beyondpenguins.ehe.osu.edu/issue/energy-and-the-polarenvironment/questioning-techniques-research-based-strategies-for-teachers

7. Goldhaber D and Brewer . (n.d.) Evaluating the Effect of Teacher Degree Level on Educational Performance . Retrieved August 29, 2016 from http://nces.ed.gov/pubs97/975351.pdf.

8. Geronimo J. Many schools not yet training teachers for $K$ to 12. (2013) Files from COCOPEA. Retrieved August 30, 2016 from http://www.rappler.com/nation/89892-pia-cayetano-training-teachers-k12

9. Hoglund B. and McClung C. ( 2012). Teaching Quality Impacts Student Achievement. ASQ Primary and Secondary Education Brief March 2012 (Vol. 5, No. 3). Retrieved August 29, 2016 from http://rube.asq.org/edu/2012/03/continuous-improvement/teaching-quality-impacts-student-achievement.pdf

10. Ingersoll, Richard ( 2003). Out-of-Field Teaching and the Limits of Teacher Policy. A Research Report cosponsored by Center for the Study of Teaching and Policy and The Consortium for Policy Research in Education . Retrieved July 18, 016 from https://depts.washington.edu/ctpmail/PDFs/LimitsPolicy-RI-092003.pdf

11. King Rice, J. (n.d.). Teacher Quality: Understanding the effectiveness of teacherAttributes. Retrieved July 19, 2016 from http://eric.ed.gov/?id=ED480858

12. Kola, A.J \& Sunday, O.S. (2015). A Review of Teachers' Qualifications and Its Implication on Students' Academic Achievement in Nigerian Schools

13. Loewenberg D. and Williamson (n.d.) The Subject Matter Preparation Of Teachers. Retrieved July 29,2015 from McDiarmid2http://www.educ.msu.edu/NCRTL/PDFs/NCRTL/IssuePapers/ip894. Pdf

14. Macarandan, Rose Marie S. Assessment of the Araling Panlipunan Modules in the K-12 Curriculum: Enhanced Instructional Materials Development. International Conference on Economics, Social Sciences and Languages (ICESL'14) May 14-15, 2014 Singapore. Retrieved August 29, 2016 from http://icehm.org/upload/2055ED0514045.pdf

15. Marzano, R., D. Pickering, and J. Pollock. (2011). Classroom instruction that works: Research-based strategies for increasing student achievement. Alexandria, VA: Association for Supervision and Curriculum Development. Retrieved August 30, 2016 from http://beyondpenguins.ehe.osu.edu/issue/energy-and-the-polarenvironment/questioning-techniques-research-based-strategies-for-teachers

16. Medwell, J., Wray D., Poulson L., Fox, R. Effective Teachers of Literacy. Education Line. Retrieved August 29, 2016 from http://www.leeds.ac.uk/educol/documents/000000829.htm\#ch2

17. The National Academic Press. ( 2015). The Critical Importance of Well-Prepared Teachers for Student Learning and Achievemen. Retrieved May 12, 2016 from http://www.nap.edu/read/9832/chapter/5

18. Ohio Teacher Evaluation System ( 2015). Retrieved Augts 16, $2016 \quad$ from https://education.ohio.gov/getattachment/Topics/Teaching/Educator-Evaluation-System/Ohio-s-Teacher-

Evaluation-System/Teacher-Performance-Ratings/OTES-Model-122315.pdf.aspx

19. Owolabi, O.T. (2012). Effect of Teacher's Qualification on the Performance of Senior Secondary School Physics Students. Ekiti State University, Nigeria. Department of Curriculum Studies, Ekiti State University, Ado-Ekiti, Nigeria Retrieved August 1, 2015 from http://files.eric.ed.gov/fulltext/EJ1079503.pdf

20. PTFE, (2008) The Philippine main education highway: Towards a knowledge-based economy, Office of the President of the Philippines.

21. Resourcing and Materials. ( n.d.). Retrieved August 29, $2016 \quad$ from http://www.tllg.unisa.edu.au/lib_guide/gllt_ch4.pdf

22. Rolluqui, G. (n.d.) Instructional Media for Different Levels $n$ the Philippine Educational System. Unpublished Research. Technological University in the Philippines. Retrieved August 15, 2016 from 
https://www.academia.edu/9574342/The_Instructional_Media_for_Different_Levels_in_the_Philippine_Educat ional_System

23. Samillano, Joseph ( 2015). Competency Among MAPEH Teachers in Teaching Performing Arts in Selected Public Secondary Schools in North Cotabato.

Writing). University of Southern Mindanao. Retrieved July 9, 2015 from http://www.academia.edu/11417973/Competency_Among_MAPEH_Teachers_in_Teaching_Performing_Arts_ in_Selected_Public_Secondary_Schools_in_North_Cotabato

24. Seebruck R.( 2015). Teacher Quality and Student Achievement: A Multilevel Analysis of Teacher Credentialization and Student Test Scores in California High Schools. Sociological Review, Volume 5 (July 2015): 1-18. University of Arizona. Retrieved August 12, 2016 from https://www.mcgill.ca/msr/msr-volume5/teacher-quality-and-student-achievement

25. Sockalingam, N. (2011). Questioning Skills to Engage Students. Faculty Focus, Higher Ed Teaching Strategies. http://www.facultyfocus.com/articles/teaching-and-learning/questioning-skills-to-engage-students/

26. Syed Shafqat Ali Shahthe (2009). Impact of Teacher behaviour on the Academic Achievement of the Students. ( Unpublished Dissertation Writing. Retried August 29, 2016 from http://prr.hec.gov.pk/Thesis/293S.pdf

27. The Impact of Individual Teacher on Student Achievement, Retrieved August 29, 2016 from https://www0.gsb.columbia.edu/faculty/jrockoff/rockoff_teachers_march_04.pdf

28. Valisno, M.D. (2012). The Nation's Journey to Greatness: Looking Beyond Five Decades of Philippine Education, FAPE.

29. Xiaoyan Ma. ( 2008). The Skills of Teacher's Questioning in English Classes. International Education Studies. Retrieved August 30, 2016 from http://files.eric.ed.gov/fulltext/EJ1065462.pdf

30. Zhang Danhui ( 2008). The Effect of Teacher Education Level, Teaching Experience, and Teaching Behaviors on Student Science Achievement. ( Unpublished Dissertation Writing, Utah State University). Retrieved August 29, 2016 from http://digitalcommons.usu.edu/cgi/viewcontent.cgi?article=1167\&context=etd

31. Zuzovsky, R. (2003). Teachers' Qualifications and their impact on student achievement, Center for Science and Technology Education, Tel Aviv, Israel. Retrieved July 18, 2015 from http://www.ierinstitute.org/fileadmin/Documents/IERI_Monograph/IERI_Monograph_Volume_02_Chapter_02 pdf. 